\title{
WPS3555
}

\section{HOW DOES THE COMPOSITION OF PUBLIC SPENDING MATTER?}

\author{
Stefano Paternostro, Anand Rajaram and Erwin R. Tiongson \\ PRMPR and PRMPS \\ The World Bank, 1818 H Street, NW, Washington, DC 20433
}

World Bank Policy Research Working Paper 3555, March 2005

The Policy Research Working Paper Series disseminates the findings of work in progress to encourage the exchange of ideas about development issues. An objective of the series is to get the findings out quickly, even if the presentations are less than fully polished. The papers carry the names of the authors and should be cited accordingly. The findings, interpretations, and conclusions expressed in this paper are entirely those of the authors. They do not necessarily represent the view of the World Bank, its Executive Directors, or the countries they represent. Policy Research Working Papers are available online at http://econ.worldbank.org. 


\begin{abstract}
Public spending has effects which are complex to trace and difficult to quantify. But the composition of public expenditure has become the key instrument by which development agencies seek to promote economic development. In recent years, the development assistance to heavily indebted poor countries (HIPCs) has been made conditional on increased expenditure on categories that are thought to be "pro-poor".

This paper responds to the growing concern being expressed about the conceptual foundations and the empirical basis for the belief that poverty can be reduced through targeted public spending. While it is widely accepted that growth and redistribution are important sources of reduction in absolute poverty, a review of the literature confirms the lack of an appropriate theoretical framework for assessing the impact of public spending on growth as well as poverty. There is a need to combine principles of both public economics and growth theory to develop appropriate theoretical guidance for public expenditure policy.

This paper identifies a number of approaches that are beginning to address this gap. Building on these approaches, it proposes a framework that has its foundation in a broadly articulated development strategy and its economic goals such as growth, equity, and poverty reduction. It recommends the use of public economics principles to clarify the roles of the private and public sectors and to recognize the complementarity of spending, taxation, and regulatory instruments available to affect public policy. With regard to the impact of any given type of public spending, policy recommendations must be tailored to countries and be based on empirical analysis that takes account of the lags and leads in their effects on equity and growth and ultimately on poverty. The paper sketches out such a framework as the first step in what will have to be a longer-term research agenda to provide theoretically and empirically robust and verifiable guidance to public spending policy.
\end{abstract}

JEL Classification Numbers: H11, H50, I38

Keywords: expenditure allocation, poverty reduction, growth, equity 


\section{HOW DOES THE COMPOSITION OF PUBLIC SPENDING MATTER? A Framework Relating Public Spending to Growth, Equity and Poverty REDUCTION OBJECTIVES ${ }^{1}$}

\section{INTRODUCTION}

Whereas development objectives in the post-war period were typically cast in terms of economic growth, in recent years, a number of initiatives have emphasized poverty reduction as a primary development policy goal. ${ }^{2}$ In 1999 , a number of modifications were made to the Heavily Indebted Poor Countries (HIPC) Initiative, to strengthen the links between debt relief, social policies and poverty reduction. In 2000, under the auspices of the United Nations, the international community reached broad agreement on the Millennium Development Goals (MDGs), including explicit targets for poverty reduction. Meanwhile, among developing countries, there has been emphasis on producing country-driven Poverty Reduction Strategy Papers (PRSPs) to provide the policy framework for achieving economic growth and poverty reduction, as well as for coordinating donor efforts. Together, these initiatives have led to increased efforts to identify specific policies and programs for effectively reducing poverty.

Over the last five years donors have required governments to identify and increase the share of "pro-poor" expenditure in the context of the enhanced HIPC Initiative and PRSP implementation. A review of experiences with pro-poor budgeting in countries that have reached the Decision Point of the Enhanced HIPC Initiative suggests that education and health care are consistently classified as "poverty-reducing" (Figure 1). In contrast, the classification of other expenditure components (such as agricultural development and infrastructure) as "poverty-reducing" varies from country to country.

\footnotetext{
${ }^{1}$ We received valuable comments and suggestions from: Sudharshan Canagarajah, Shanta Devarajan, Lionel Demery, Alan Gelb, Maureen Lewis, Humberto Lopez, Sanjay Pradhan, Sudhir Shetty, Vera Wilhelm, participants at the 2004 PREM Learning Week session, "Pro-Poor Expenditures: A Debate" (May 4, 2004) and participants and discussants at the ODI workshop, "Current issues and debates in Aid \& Public Expenditure Management" (May 13-14, 2004). The usual disclaimer applies.

${ }^{2}$ Mention should be made of the concept of Human Development that was introduced by Mahbub al Haq and UNDP in the 1990s and was used to make the case that economic growth was the means to achieve human development, measured by a composite index based on life expectancy, adult literacy, school enrollment and GDP per capita. In 1994 a "human development 20:20 compact" was proposed to earmark 20\% of aid flows and $20 \%$ of govt. budgets to basic social services. This compact may have laid the groundwork for the subsequent HIPC emphasis on public spending on health and education as key to human development and, by association, with poverty reduction (see Human Development Report 1996).
} 


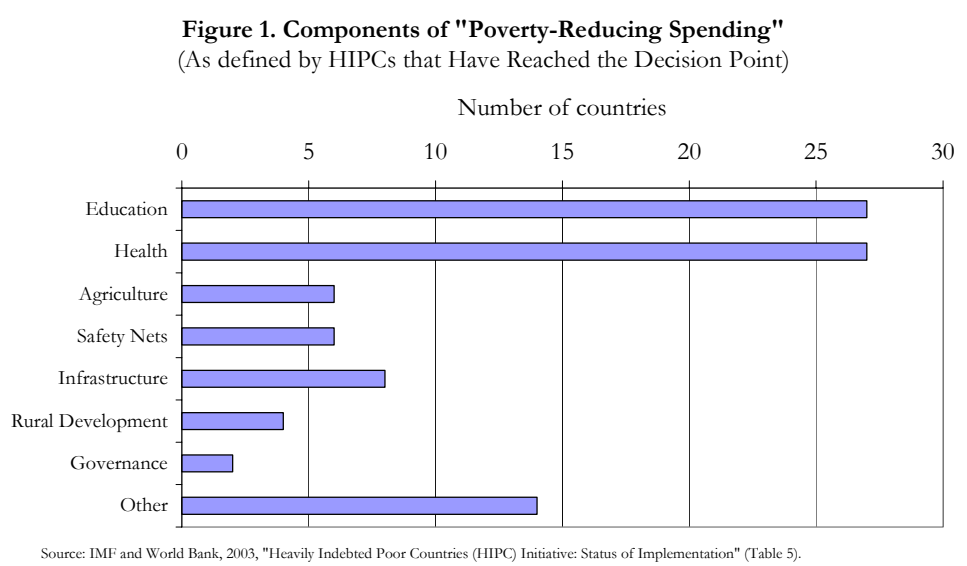

A recent review of the Enhanced HIPC Initiative conducted by the World Bank's Operation Evaluation Department (OED) confirms that the Initiative has indeed earmarked debt relief "savings" for poverty reduction, which has in turn been translated into substantial allocations of debt relief resources for social expenditures (World Bank 2003b). In particular, the increased resources provided by debt relief have been disproportionately targeted for allocation to the social sectors, for a sample of HIPC countries for which data were available (Figure 2). Of the total amount of resources, some 49 percent were allocated to the education and health sectors (World Bank, 2003b).

Academic studies, perhaps following this trend, have also used social spending or spending on the education and health sectors as a proxy for pro-poor spending (See Appendix I). Using this definition, studies have tried to estimate the statistical relationship between aid flows and pro-poor budgets (e.g., Gomanee, Girma, and Morrissey 2003), or to determine whether decentralization leads to higher pro-poor spending (e.g., Schneider 2003), or to simply assess a country's fiscal stance (e.g., Mooji and Dev 2004).

Figure 2. The Projected Allocation of HIPC Resources

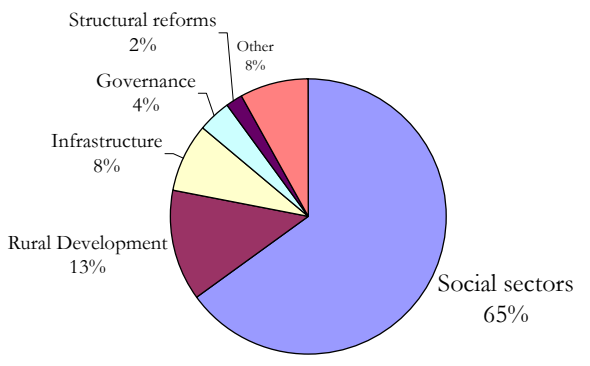

World Bank, 2003, The Heavily Indebted Poor Countries (HIPC)

What accounts for the unusual consensus regarding social sector spending as key to poverty reduction? The OED study suggests that these conditions are a result of the demand by the advocacy NGOs, who have equated poverty reduction with social expenditures. Other proponents argue that the donor bias toward direct spending on the 
poor should be seen as a countervailing measure to the tendency for political elites in recipient countries to influence the allocation toward programs which cater to their needs rather than those of the poor. ${ }^{3}$

There is, however, growing concern regarding the wisdom of relying so heavily on social sector spending to promote poverty reduction. The OED finds that a different balance between social and other sectors, particularly infrastructure and rural development, may be warranted for mobilizing investment to promote growth, a necessary condition for sustainable poverty reduction. Killick (2004) utilizes the OED's findings to argue forcefully that large amounts of aid are being misdirected, promoting a narrow approach to poverty where spending in the social sectors is expanded at the expense of broader developmental priorities such as raising economic growth and addressing structural weaknesses, both of which are key to sustained poverty reduction. In Uganda, it has been argued that roads, agriculture and water and sanitation may yield higher returns for employment and income creation than primary health care and education and that the Poverty Action Fund has promoted a narrow interpretation of pro-poor programs, skewing budget allocations away from programs that may have allowed greater poverty reduction. (Williamson and Canagarajah 2003, World Bank 2002)

The social sector bias in pro-poor allocations is also present in the PRSP programs which include countries not eligible for HIPC assistance. In a review of the role of PRGF programs in supporting PRSPs, the Independent Evaluation Office (IEO) of the IMF reached similar conclusions.

"Strategies outlined in PRSPs generally constitute an improvement over previous development strategies, in the sense of providing greater poverty focus, a longerterm perspective, and some results-orientation. However, most PRSPs fall short of providing a strategic roadmap for policy making, especially in the area of macroeconomic and related structural policies. The focus of most PRSPs is on the composition of public expenditures, especially social sector spending, with much less emphasis on other aspects of a broader strategy to encourage poverty-reducing growth [emphasis ours]." (IMF 2004: 4)

\section{Methodological ConCERnS AND Issues}

One of the weaknesses of the pro-poor approach is that it has used facile reasoning to link inputs (public spending) and outcomes (absolute poverty levels). An unintended consequence of this approach is that it has suppressed the essential discussion of the linkages between public spending policy and its direct and indirect effects and short and long term consequences. The effects of a public policy on policy objectives (such as absolute

\footnotetext{
${ }^{3}$ An Overseas Development Institute (ODI) review (Foster and others (2002)) of the experience with pro-poor budgeting in five sub-Saharan African countries observed that the criteria for what constitutes poverty-reducing expenditure have generally focused on direct benefits to the poor. They suggest that the general tendency of equating poverty reduction with social service provision needs to be seen in historical context as a compensation for previous neglect of services to the poor.
} 
poverty) can only be verified if the transmission channels and the time period for effects to be observed are reasonably well-defined. Absent this, one has to make a leap of faith to link inputs and outcomes. So, from an empirical point of view, the validity of this approach to poverty reduction is difficult to test and to compare and contrast with alternative poverty reduction policies.

A second criticism of the pro-poor expenditure approach is that it obscures the contribution of economic growth-promoting interventions and contributes to a false dichotomy between growth and poverty reduction. The argument could be made, if one were to be charitable to its proponents, that the pro-poor approach is a "reduced form" of a broader "structural" development policy, subsuming the effects of public policy on related but subsidiary objectives such as growth and equity. But such a reduced form is not helpful if it contributes to the impression that poverty can be reduced "directly" by sidelining or ignoring the effects of policy on growth and equity. The evidence cited above, of spending policy applied to real countries, suggests that both donors and governments have been tempted to think that this is the case. ${ }^{4}$

The international commitment to the Millennium Development Goals and the debate about the appropriate levels of aid to achieve the goals only reinforce the concern that public spending and outcomes are being linked with misleading simplicity and with little reference to economic theory and development experience. The World Bank's 2004 World Development Report provides ample illustration of why the link between public expenditure and its ultimate impact in improving any desired outcome for the poor, such as literacy or health status, is fraught with problems, including problems of diversion of resources to the non-poor, poor quality of services, lack of access, and absenteeism by service providers, all examples of government failure.

One would have to look to both applied welfare economics and the theory of economic growth to derive the necessary guidance on if and how public spending could be used to stimulate growth, improve the distribution of income and reduce poverty. Section III of this paper provides a synopsis of existing theoretical and empirical perspectives on the appropriate allocation of government expenditure for poverty reduction for which more extensive discussion is provided in an annex. The review of the literature reveals a surprising paucity of useful guidance on this topic ${ }^{5}$, which might serve to explain why development agencies have used ad hoc and simplistic principles to respond to political pressure in donor countries to link debt relief and aid flows to poverty reduction.

In the absence of clear guidance from economic theory, section IV proposes a pragmatic framework, consistent with public economics principles and (to a lesser extent) what is known from growth theory, to guide empirically testable hypotheses regarding the

\footnotetext{
${ }^{4}$ A considerable amount of intellectual effort is consequently directed to debating and clarifying issues that would be better spent on real problems. See for example Dani Rodrik, "Growth versus Poverty Reduction: A Hollow Debate" (Finance and Development, December 2000, http://www.imf.org/external/pubs/ft/fandd/2000/12/rodrik.htm).

${ }^{5}$ Perotti (2003) also notes the absence of a coherent model for evaluating the trade-offs between different expenditure programs.
} 
growth and poverty impact of expenditure policy choices. The framework encompasses a government's development strategy with explicit recognition of its goals for growth, equity and poverty reduction as well as key social indicators. It underlines the importance of public economics principles in identifying the appropriate roles of the public and private sectors, and the recognition of the full scope of public policy instruments - the regulatory framework (broadly defined to include property rights, security and law and order), and tax and expenditure policy - available to achieve policy objectives. The framework allows a focus on the policy implications of allocating resources among sectors and government programs, with respect to their direct and indirect effects on poverty as well as their immediate and lagged impact. The paper also identifies ways of quantifying the links between variables in the framework using existing tools and reviews selected empirical work where this has been undertaken. Finally, Section V discusses the policy implications and suggests some practical operational guidelines for development agencies such as the World Bank for improving the analytical basis for linking public spending to economic growth, equity and poverty reduction.

\section{A SyNOPSIS OF THE Literature ON EXPENDitURE AlLOCATION}

How should a government allocate public spending across various sectors to maximize prospects for achievement of its development (growth and poverty reduction) objectives? What principles and technical tools should guide the allocation of resources? What is current guidance on these questions?

It is important to recognize that, unlike tax policy, where the theory of optimal taxation was developed, there is not a comparable theory of optimal expenditure policy that provides comparably well-defined rules for expenditure allocation. The key ideas of expenditure policy were the concepts of externalities and market failure that suggested that only "efficiency enhancing" interventions that corrected for the underprovision of a product or service due to market failure justified public expenditure. ${ }^{6}$

Because of the lack of clear theoretical results, the various guidelines proposed and used by public finance specialists and staff members of the World Bank ${ }^{7}$ and other IFIs ${ }^{8}$ for considering general issues on expenditure allocation are pragmatic "good analytical practice" adaptations to the current state of knowledge. ${ }^{9}$

\footnotetext{
${ }^{6}$ Devarajan, et.al. (1996) observe that "neither economic theory nor empirical evidence provides clear-cut answers to how the composition of expenditure affects economic growth". It might be added that neither does theory indicate clearly how expenditure affects equity or poverty.

${ }^{7}$ See for example, Devarajan et.al., 2001; Pradhan, 1996; IMF, 1995.

${ }^{8}$ Such as the International Monetary Fund (IMF), the Asian Development Bank (ADB), and the Organisation for Economic Cooperation and Development (OECD).

${ }^{9}$ While staff members of international organizations have recently developed practical guidelines for expenditure analysis, the theory of public expenditure has, as is well known, a very long history. Musgrave (1985) traces notable contributions in the development of principles of expenditure allocation, including those of Lindahl (1918) and Pigou (1928) in the application of the theory of marginal utility to government expenditures, Samuelson's $(1954,1955)$ path-breaking linkage of externalities and social goods and integration of social goods into principles of efficiency, and the development of cost-benefit analysis in the 1960s. Walker (1930) provides one of the first surveys of the theory of public expenditures.
} 
The guidelines suggest the following ${ }^{10}$ :

General principles. As indicated above the guidance on expenditure allocation has emphasized the principle of public economics i.e. to identify interventions that address market failures and inefficiencies. ${ }^{11}$ Existing guidelines call for an assessment of the proper role of government, by clarifying private-public roles and evaluating market failure. Whether an expenditure is warranted should be determined by whether it would address a market failure or achieve an equity objective. There is typically an appraisal of the relative efficiency of various tools, government interventions, and expenditure policy options, for achieving particular objectives. This suggests distinguishing between financing a good or service and provision of that good or service.

Menu of technical tools. For evaluating expenditure options, guidelines provide a menu of available technical tools for steering policy choices, including cost-effectiveness analysis, multi-criteria analysis, service delivery surveys, expenditure tracking, and social cost-benefit analysis. To the extent that the guidelines discuss the equity objective it is to refer to established methodologies such as benefit incidence analysis.

What is the consensus on the usefulness of quantitative techniques for guiding resource allocation? Some guidelines are less confident about the value of existing empirical tools (for example, World Bank, 1993). Some sectors lend themselves more easily to economic cost-benefit analysis. For others, the criteria are less well defined. In theory the allocation of resources across programs should be based on the highest returns. In practice, a full economic analysis will not be possible except for a few sectors. Even within sectors that lend themselves to quantitative analysis, existing data may be inadequate for conducting a proper analysis. In this case, some guidelines suggest alternative resources for evaluating expenditure options, including the existing body of experience on how programs work in a country and experiences in other countries with similar characteristics. In practice, it may be optimistic to think that there exists a body of empirical work that quantifies all the critical parameters necessary for allocation decisions. There is then a large premium on professional judgment, based on expertise by sector and by country.

Dynamic effects. To the extent that there is reference to the impact of public spending on the poor, existing guidelines typically do not distinguish the short versus the long term, nor the direct versus indirect impact on poverty. Most policy interventions have multiple effects on poverty — which can be distinguished in terms of whether the impacts are immediate or occur with a lag and whether they are direct or indirect (through economic growth). As discussed in section 1, many of the policy initiatives in the context of PRSPs and HIPC have focused on the direct effects and while spending on health or education would be expected to have a longer-term effect on poverty, the sequence and time lags have not been adequately explained. An important exception is a framework developed by Ferroni

\footnotetext{
${ }^{10}$ A more detailed review of the recent literature appears in Appendix II. See also Fozzard (2001).

11 The Bank's PER guidelines note that the rationale for public intervention could be either market failure (public goods, externalities) or redistribution. If the former, it suggests obtaining quantitative estimates for the degree of market failure to supplement arguments based on first principles. If the rationale is redistribution, it recommends analysis of the incidence of public expenditures.
} 
and Kanbur (1992) for public expenditure restructuring taking into account both human resource interactions and multidimensionality of the standard of living. They make a distinction between direct expenditure (expenditure in the primary sector in which one seeks to obtain improvements) and indirect expenditure (income-enhancing expenditure). The analytical results imply that there is a case for a combination of both "direct" and "indirect" spending to maximize the standard of living, subject to further empirical verification.

Policy tools and the nature of poverty. In addition to the dynamic effects of expenditure allocation on poverty, the choice of public intervention must also take account of the nature of the poverty being addressed. For example, with respect to transient poverty (poverty associated with abrupt changes in economic conditions), short-run public programs (public relief, food aid, severance pay) may be appropriate. In the case of chronic poverty, two sets of public interventions are appropriate: the first increases the productivity of the poor; the second provides safety nets. Alternatively, some have suggested an assessment of how the poor can gain from various types of public interventions that affect inputs, distinguishing whether an intervention raises input volumes, improves factor productivity, or alters prices (Lipton and Ravallion, 1995).

Broader consideration. Finally, there are critical, broader considerations for considering alternative government interventions. These include income distributional effects, complementarities between expenditure items, the net impact of the combination of various government tools, and others. Some specialists have presented a more comprehensive framework within which to think about government programs for poverty reduction (Duncan and Pollard, 2002). Within this framework, they have identified the building blocks necessary — such as social order, good governance, and functioning markets-prior to any government investment for poverty reduction.

Future challenges. A recent symposium on public economics with papers by eminent economists suggested some important conclusions. ${ }^{12}$ Principally it pointed to the inadequacy of public economics theory and the failure of research to keep pace with the challenges of development policy and in providing the necessary guidance on expenditure allocation to policy makers and development practitioners. The gap between practice and theory, already noted, has widened over the past decade, particularly because the conception of development and the role of government have been significantly modified. One of the symposium contributors, Stiglitz, noted that new thinking was required because of: (a) the recognition that market failures are not special cases but are often pervasive, especially in developing countries, given the problems of incomplete markets and information; (b) the acknowledgement of government failures due to difficulties of collective action, free ridership, credibility of commitment and problems of establishing incentives for performance; and (c) an increased focus on process issues as important for desirable outcomes, such as participation by the poor. In his summary, Stiglitz noted:

\section{(A)Iternative conceptions of equity represents one of the more important changes in public policy thinking over the past quarter of century: an evaluation of economic systems not just in terms of final outcomes (e.g. the steady state distribution of income), but in terms of dynamics and process - we}

\footnotetext{
12 April 2002 Symposium, Journal of Public Economics 86 (2002) 311- 360.
} 
evaluate systems in terms of equality of opportunity, in the seeming faimess of the system. Here too, practice may have outpaced theory: there has been only limited progress in welfare economics in developing the conceptual framework and analytic tools. This too remains one of the important challenges for the coming decades.

The agenda posed by Stiglitz is beyond the scope of this paper but the framework discussed in the next section attempts to fill some of the gaps between practice and theory as a step toward that agenda.

\section{A Framework for ANalysis of the Impact of Public SPENDing on GROWTH AND POVERTY REDUCTION}

This section presents an analytical framework for relating public policy to growth and poverty, taking account of some of the dynamics of poverty reduction. The framework is based on an explicit consideration of tradeoffs between expenditure policy choices as an aspect of the broader policy choices facing a government as part of its development strategy. This section then reviews examples of policy interventions for poverty reduction and illustrates how these interventions could be evaluated within the proposed framework. It also provides an overview of existing tools for quantifying some of the parameters of the framework.

\section{Public Policy, Growth, Equity and Poverty: A Framework}

The foundation of the framework is the country's development strategy which would define the objectives and policies for growth, equity, poverty reduction and social indicators. For any given objective, the development strategy is a point of reference that is country specific. It represents a country's vision of its strengths and capabilities and its aspirations, as articulated or influenced by its (presumably representative) political leadership.

The development strategy would be determined, inter alia, by initial endowments including institutional capabilities, the demographic and geographic character of poverty and the identified bottlenecks to growth in a given economy.

The framework is presented in Figure 3 with the development strategy described partly in the form of a decision tree but with key analytical linkages to the objectives of growth, equity and poverty and social indicators heuristically indicated. A fundamental aspect of the development strategy (and an early branch of the tree) is with regard to its definition of the roles of the public and private sectors. Different development strategies might give more or less weight to the public sector and refer to a variety of institutional arrangements and policy instruments through which the strategy is implemented. Strategies might also differ with regard to the weights assigned to the different policy objectives of income growth, equity, income poverty and social indicators. Thus, this framework is sufficiently general and can accommodate a variety of strategies. 
Figure 3. Public Policy, Growth and Poverty: A Framework

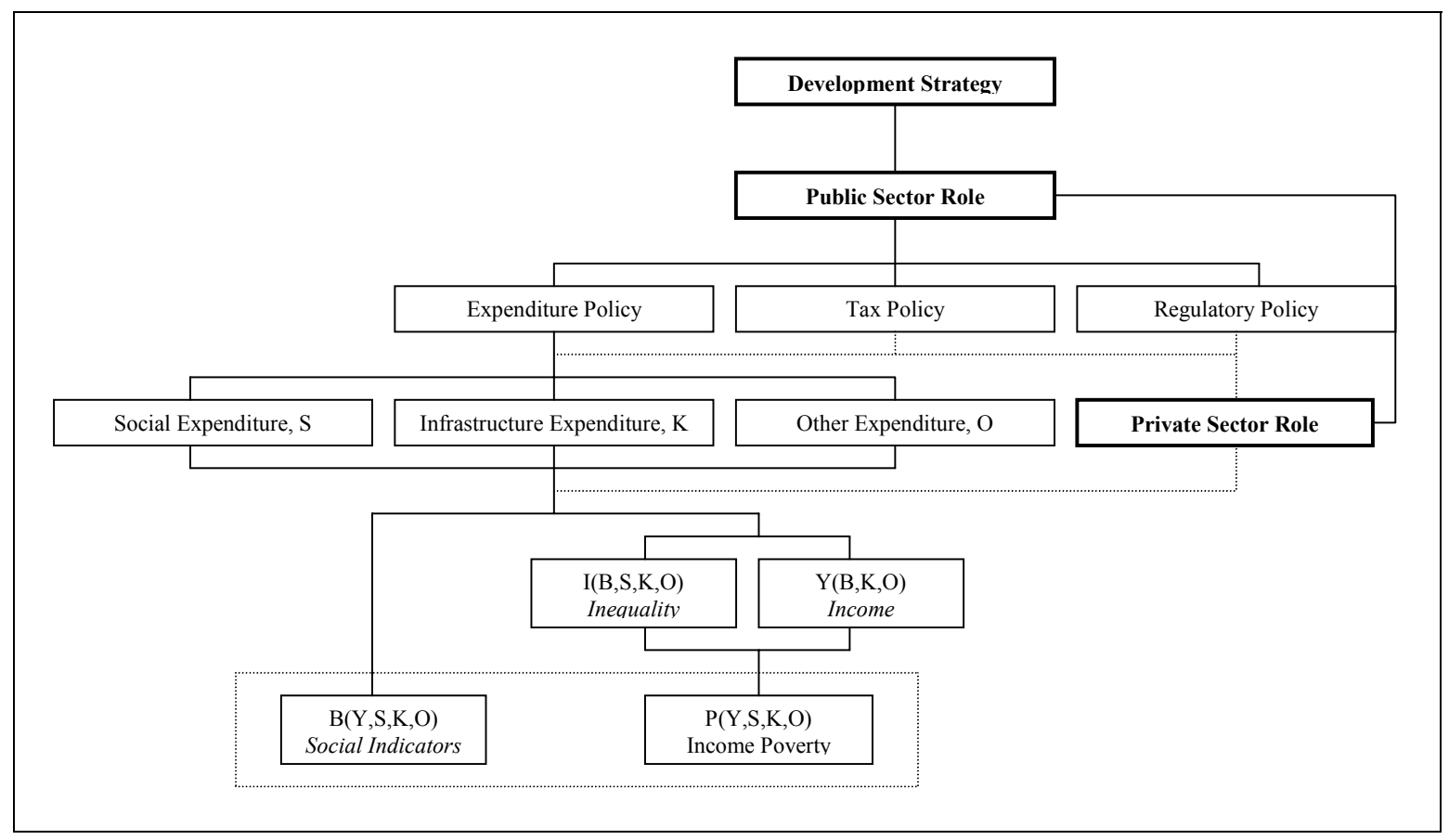

For any given determination of the relative roles of the public and private sectors, the framework identifies three broadly defined public policy instruments that can be used to stimulate the economy toward achievement of the policy objectives. These are explicitly identified in the framework as expenditure policy, tax policy and regulatory policy.

As instruments of public policy these three instruments both define key aspects of the public sector as well as establish the regulatory/incentive environment for the private sector. The chart indicates that public policies affect the objectives both directly through public sector activities as well as through their impact on the private sector.

The regulatory policy framework establishes the rules of the game and the economic environment for the private sector as well as the public sector. Minimum wage and child labor regulations, to cite two obvious examples, have an impact on the private and public sectors and through them on the earnings of workers, including the poor. Worker safety regulations affect both the public and private sectors.

Tax policy raises the necessary resources for public programs, but how these resources are raised matters for growth, equity and poverty reduction. Taxes, for example, may be regressive, may distort private sector incentives, lower aggregate investment and growth, limit households' access to critical basic services, and thus effectively exacerbate poverty.

Expenditure policy, in terms of the level and composition of expenditure specifically, can be used to influence policy objectives. While acknowledging that there are a number of ways to describe a government's expenditure policy options, this paper defines the spending choices broadly as social expenditures, infrastructure expenditure and other 
expenditure. ${ }^{13}$ The level and composition of expenditure is presumed to influence income, equity, poverty and social indicators.

There are a number of advantages to having such an explicit framework.

First, as noted, the framework has fairly general application. It is not predicated on an activist, interventionist government - in principle the role of the government might be limited to establishing property rights and ensuring law and order and national defense. Or, depending on the development strategy, it might feature a more active role for the state in terms of the level and scope of public goods and services, regulations, and revenue raising.

Second, in evaluation of a given development strategy, it allows the application of public economics principles to determine if the role of the public sector is consistent with principles of efficiency and equity, i.e. to determine whether a market failure, externality or equity rationale exists to justify public sector intervention.

Most government policy, however, is stated in terms of economic growth, employment creation and poverty reduction (rather than efficiency and equity). If development policy is to respond to these objectives, it is necessary to go beyond the public economics framework and to assess the contribution of public policy to economic growth and equity. By attempting this link between public economics and growth theory, this framework proposes an analytically challenging but also a more intuitive and recognizable framework for policy makers. By highlighting the significance of the development strategy in conjunction with the principles of public economics and economic growth, this framework provides a more comprehensive basis for evaluating public policy, including public expenditure composition, in terms of its contribution to the dynamics of growth and poverty. Even in cases where government policy is not justified from a public economics perspective but is seen to be consistent with the development strategy, there is still a need and a basis for an empirical assessment in terms of the effectiveness of such policy in promoting growth and poverty reduction. ${ }^{14}$

Another advantage is that the framework nests the expenditure allocation choice within the wider array of public policy tools at the government's disposal. Acknowledging the alternative policy instruments helps to avoid the tunnel vision that is often present in discussions of public spending wherein the response to a policy objective often is to propose increased spending on related activities. This framework encourages effective choice of policy instruments and acknowledgement of the cross-sectoral effects of public policy.

13 Budgets can be described using an economic classification, or a functional classification, or an administrative classification or a program classification. Atkinson, et al. also apply a classification that is consistent with a public economics approach, dividing up the budget into expenditure associated with pure public goods, merit goods, income transfers and economic services.

${ }^{14}$ Dani Rodrik (2003) has argued that successful economies have employed pragmatic and non-unique institutional arrangements to achieve "first-order economic principles" — protection of property rights, marketbased competition, appropriate incentives, sound money, etc. Thus the appropriate role for the public sector and the composition of public spending is itself an issue of development strategy that must be defined by country circumstances and capabilities and is not uniquely pre-determined. This framework would support a more creative, less doctrinaire but ultimately more empirical basis for policy analysis and advice. 
Conceivably, a regulatory policy reform that increases incentives for private road maintenance might have a more beneficial impact on education or health indicators than direct spending on education or health.

Finally, the framework can (and should) be made more detailed and specific to the country context, and used to define and empirically assess specific linkages between public policy and its impact on various policy objectives. Thus it encourages an empirically more rigorous approach to public policy and helps identify linkages to growth and poverty about which there is inadequate knowledge. ${ }^{15}$

\section{Public Expenditure Policy, Growth, Equity and Poverty}

Within the broad framework defined above, this paper focuses on the analysis of expenditure choices and their impact on growth and poverty, building on the expenditure allocation framework of Ferroni and Kanbur (F-K hereafter). F-K cast the problem as an allocation choice between "social" expenditure and "infrastructure" expenditure (physical capital $)^{16}$ with the objective being to maximize the standard of living (W). In reallocating resources between social and infrastructure to maximize $W, \mathrm{~F}-\mathrm{K}$ show that the choice depends on the total welfare effects working through both basic needs and income mechanisms. We adapt the F-K framework but with several important modifications, allowing a choice among social expenditure, infrastructure spending and other spending, introducing inequality (I) as a policy variable, and identifying headcount poverty and selected social indicators as key policy objectives.

* The budget constraint, $\mathrm{R}=S+K+O$, indicates that government revenue $\mathrm{R}$ can be spent on social $(\mathrm{S})$, infrastructure $(\mathrm{K})$ or other $(\mathrm{O})$ expenditure. ${ }^{17}$ The framework suggests that the level and composition of spending have an effect on basic social indicators $(\mathrm{B})$, income $(\mathrm{Y})$, inequality $(\mathrm{I})$ and poverty $(\mathrm{P})$.

* Basic social indicators (B) (e.g., health status, education achievement, etc.), are a function of social, infrastructure and other expenditure $(\mathrm{S}, \mathrm{K}, \mathrm{O})$ and income $(\mathrm{Y}) .^{18}$ Thus $\mathrm{B}=f(S, K, O, Y)$.

\footnotetext{
15 Bannerjee and He (2003) critique the World Bank for not making adequate use of scientific evidence to test ideas before they are recommended or advocated as good practice in development. The advocacy and application of the concept of pro-poor expenditure as policy is a good example of an idea unsupported by analysis.

${ }^{16}$ We recognize the problems introduced by this taxonomy of public spending. We explored other taxonomies but found them even more unsatisfactory. For example, some distinguish between investment in "services" and investment in "growth." F-K distinguish between social expenditure and "productive" expenditure. There are of course clear reasons to expect social spending to be just as productive as the so-called productive expenditures.

17 Other expenditure would include general administration expenses as well as law and order and security related expenditure.

${ }^{18}$ Some have argued that $\mathrm{B}$ is also a function of income inequality (I) as well; thus, $\mathrm{B}=\mathrm{f}(\mathrm{S}, \mathrm{K}, \mathrm{O}, \mathrm{Y}, \mathrm{I})$. In particular, some papers have provided evidence that more equal societies are healthier (Wilkinson 1992; Kawachi, Kennedy, and Wilkinson 1999). However, Deaton (2003) has been critical of this literature. The main conclusions that follow from our framework hold, regardless of whether or not social indicators are a function of income inequality.
} 
* Income $Y$ is a function of $B$ and infrastructure and other expenditure, $Y=f(B, K, O)$.

Income inequality (I) is assumed to be function of basic needs achievement (B), social expenditure $(\mathrm{S})$, infrastructure expenditure $(\mathrm{K})$ and other expenditure $(\mathrm{O}) .{ }^{19}$ This gives the following: $I=f(B, S, K, O)$.

* Poverty $P$ is a function of $S$ (e.g., transfers), I, and $Y, P=f(Y, S, K, O)$.

The government allocates resources between $S, \mathrm{~K}$ and $\mathrm{O}$, trading off their direct and indirect impact on $Y$ and $I$ as well their immediate and cumulative impact over time, to reduce the poverty headcount $P$ (implicitly also impacting growth $\mathrm{Y}$ and equity $\mathrm{I}$ ) and improve social indicators B.

It should be noted that improving social indicators and reducing poverty are objectives consistent with the Millennium Development Goals (MDGs). Though we do not refer to MDGs explicitly in the framework, the same expenditure allocation issues underpin the attainment of MDGs. However, this clearly still falls short of a multidimensional treatment of poverty. Integrating the multiple objectives of improving social indicators and reducing income poverty within an HDI-like objective function (i.e., a composite development indicator) facilitates a more explicit evaluation of tradeoffs. However, this introduces new complexities. For example, in considering the tradeoff between social and infrastructure expenditure, a multidimensional framework needs to account for social spending's short-term contribution to the improvement of social indicators as well as its longer-term contribution to growth and poverty reduction. We recognize that this is an under-researched area which deserves further investigation. For simplicity, we restrict the current analysis to the evaluation of tradeoffs in reducing absolute poverty.

Application of the Framework: Some Examples

Although the overall framework allows an assessment of expenditure, tax and regulatory policy, we focus our attention on the composition of public expenditures to illustrate the implications of this framework, consistent with the focus of this paper. In estimating the impact of an additional unit of social spending $(\mathrm{S})$ or infrastructure spending $(\mathrm{K})$ on poverty $(\mathrm{P})$ or on social indicators $(\mathrm{B})$, we need to take into account its direct and indirect impact as well as its contemporaneous and lagged impact. We consider below three typical government interventions and trace their impact on poverty.

Tax-and-transfer scheme. Consider a scheme that taxes only households in the top income quintiles. Assume that the tax revenues are used to provide transfers $(\mathrm{S})$ directly to households in the lowest quintiles. In the short-run, the scheme reduces income inequality

\footnotetext{
${ }^{19}$ We distinguish between the impact of S and B, to allow for the direct impact of selected social expenditure items (such as transfers) on $I$ that is distinct from the impact of $B$ on $I$ in the medium to long term (e.g., reduction in income inequality via human capital formation among the poor).
} 
(I) while keeping average income $(\mathrm{Y})$ constant; and the poverty headcount $(\mathrm{P})$ falls. ${ }^{20}$ Over the medium term, income $(\mathrm{Y})$ will change. Depending on the incentives and distortions created, this scheme may either increase $Y$ or reduce $Y$ (though both taxes and government transfers are usually associated with lower growth); the impact on $Y$ in the longer-run is an empirical question. The increase in transfers (S) also raises education attainment or promotes better health (B), to the extent that funds are used to finance human capital formation. Improved social indicators may lift earnings potential and worker productivity over the medium to long term, leading to a further fall in the poverty headcount (P). In sum, a tax-transfer-scheme has both an immediate impact on poverty and a lagged effect on poverty through its impact on incentives, human capital formation and income. ${ }^{21}$

Targeted investment in education from foreign grants. Consider educational expenditures financed by foreign grants. For simplicity, we assume away the potential macroeconomic consequences of sustained high inflows of external resources, such as the "Dutch disease," where the inflow of resources may have adverse effects on growth and poverty reduction via exchange rate appreciation. ${ }^{22}$ Suppose the government uses the foreign grant to expand the supply of schooling, targeted to serve the poorest households. Over the medium term, the educational attainment (B) of the poorest households will improve. Over the medium to long term, the increase in $\mathrm{B}$ raises their income $(\mathrm{Y})$ and lowers the poverty headcount $(\mathrm{P})$. Because educational spending is targeted toward the poorest households, income inequality (I) falls. ${ }^{23}$ [In terms of an initial vector of income quintiles, the scheme increases the income of the lowest quintile, $Y_{5}$, while, ceteris paribus, leaving the income of the other quintiles constant, thus reducing income inequality and the poverty headcount $(\mathrm{P})$.] In sum, a targeted investment in education financed by foreign grants has a lagged effect on poverty and education indicators via improved educational attainment among the poor.

Targeted infrastructure investment. Consider infrastructure investment (K) (e.g., rural roads) in a poor geographic areas. These projects may have an immediate impact on income $(\mathrm{Y})$ and poverty $(\mathrm{P})$. To the extent that employment opportunities are generated specifically among the poor through public works employment, this may lead to lower poverty (P) and lower income inequality $(\mathrm{I}){ }^{24}$ There are also lagged effects on income $(\mathrm{Y})$ via increased factor

\footnotetext{
${ }^{20}$ Equivalently, if a vector of income quintiles represents income distribution, the scheme increases the income of the lowest quintile, $Y_{5}$, while reducing the income of the top quintile, $Y_{1}$, thus reducing the poverty headcount $P$.

21 These statements of effects are meant to be illustrative and not intended to overstate the extent to which policy can determine such outcomes.

22 See Heller and Gupta (2002) for a review of these macroeconomic issues.

23 On the other hand, the expansion of education may be associated with greater wage inequality; for example, expanding the supply of primary education may lead to lower returns to primary education for older workers. A recent study by Duflo (2002) of education expansion in Indonesia through a large program of school construction (the Sekolah Dasar INPRES program) initiated in the 1970s finds that an increase in the proportion of primary school graduates in the labor force decreased wages of older cohorts. Duflo observes that in Indonesia's case, physical capital did not adjust to the increases in human capital in the regions where schools were built. She is unable to explain why the stock of physical capital failed to adjust despite the public announcement of the program and its gradual implementation over 10 years.

${ }^{24}$ There will be wealth effects due to increase in the value of land due, in turn, to better infrastructure. The wealth effects will accrue largely to the landowning groups. This is likely to increase inequality in the distribution of wealth.
} 
productivity, lower transactions and transport cost, expanded trade, and higher employment. Higher income may then promote human capital formation (B) through better health and higher education attainment, which, in turn, raises the earnings potential of individuals. In this framework, we do not allow for a direct impact of infrastructure investment (I) on social indicators (B), although the empirical evidence suggests that such an investment (e.g., on water and sanitation) may have important direct effects on health and nutrition (Fay, Leipziger, Wodon and Yepes 2003). In sum, infrastructure investment has both immediate and lagged effects on poverty. It has a direct effect on income as well as an indirect effect via buman capital formation.

While illustrating the approach to understanding the poverty impact of spending on any specific $S$ or $K$ sector, these examples also indicate that the framework provides a basis for considering the consequences of alternative spending choices. ${ }^{25}$ In principle, it offers the possibility of making a more informed choice between spending on $S$ or $K$ on the basis of a comparison of the short and long term and direct and indirect impact on poverty of each policy. However, such a comparison will require empirical estimation of the impact.

\section{Empirical Tools for Estimating Parameters of the Framework}

There have been significant advances in quantifying the linkages between expenditure components, on the one hand, and, economic growth, basic needs achievement, or poverty reduction, on the other hand. Some of the leading studies in this literature are cited below. However, the body of empirical evidence for setting strategic policy priorities remains incomplete. The critical gaps in the empirical literature include the following:

- Identifying the correct "production function" for poverty reduction and for improving social indicators (see, for example, Ravallion 2003).

- Comparisons of the cumulative impact of expenditure components that directly affect growth and poverty reduction with those components that have an indirect effect. Would spending diverted from transfers (which have a direct impact on poverty) to rural education (which has an indirect impact on poverty through basic needs achievement) lead to larger, and more sustained reductions in poverty?

- Comparisons of the immediate and lagged effects of expenditure components. How soon after spending is allocated to primary spending should we expect to see any impact on growth? Are there threshold effects?

To date, there has been no systematic and comprehensive assessment of the allocation of resources across sectors. Nonetheless, there are a number of recent developments in the literature that are worth noting. In particular, a series of recent papers have employed various quantitative techniques (regressions, CGE, marginal benefit incidence analysis) and used various types of data sets (e.g., cross-country, time-series, micro data, panel data) to compare marginal returns to spending across sectors. For example, Fan,

\footnotetext{
25 While the proposed framework uses a broad characterization of "social" and "productive" expenditure, it would work equally well with a more detailed functional classification of expenditure.
} 
Huong, and Long (2003) use a system of equations to model the impact of government spending on rural poverty, taking into account the impact of, on the one hand, agricultural research on productivity and, in turn, on poverty, and on the other hand, the impact of education on both productivity and employment, and, in turn, on poverty. The results allow them to compare the marginal returns to various types of government spending.

Such studies (summarized in Table 1) represent a step forward toward a more careful and comprehensive assessment of marginal returns to spending. However, as currently implemented, they also suffer various drawbacks with respect to our objectives. In a number of cases, for example, the specification seems largely ad hoc and not drawn from any existing economic theory. In addition, the expenditure components covered by these studies are often a small fraction of all expenditure options available to governments. In many cases, the time period covered is not sufficiently long to make meaningful inferences about short-term and long-term effects of spending. Nevertheless, even if the various approaches are often incomplete, important insights can still be gained into how expenditure policy leads to poverty reduction and on the enabling conditions that allow government interventions to reduce poverty. ${ }^{26}$

A more careful evaluation of marginal returns could compare the contemporaneous and lagged marginal impact on growth and poverty reduction of various expenditure components, as well as their relative effectiveness in reaching and benefiting the poor. Ideally, such an exercise would be calculated within a long-run, intergenerational, general equilibrium framework - and would thus provide estimates of the marginal returns to major expenditure items and direct the optimal allocation of limited budgets for poverty reduction, in general, or for meeting explicit goals, such as the Millennium Development Goals, in particular. For example, such an exercise could inform current efforts to simulate financing needs for achieving the MDGs (Bourguignon, and others 2004). However, it may be that such an exercise is inherently fraught with many technical difficulties (not the least of which is the scarcity of good data in many developing countries). ${ }^{27}$

\footnotetext{
${ }^{26}$ Appendix 3 provides a brief description of various tools and techniques that can be used for the analysis of public expenditure links with poverty reduction. They can be categorized in four [five] groups: (i) reduced form regressions; (ii) general equilibrium models; (iii) Investment appraisal methods; (iv) Incidence analysis;

${ }^{27}$ Literature comparing the relative efficiency of redistributive expenditure policy and redistributive tax policy is rare (see Chu, Davoodi, and Gupta 2004). Warr (2003) is one exception. He compares the impact of expenditure reform with tax reform on poverty. He also considers the likely significant effects of simultaneous changes in both the composition of taxes and the composition of revenues.
} 
Table 1. Summary of Selected Empirical Studies: Public Expenditure and Poverty

\begin{tabular}{|c|c|c|c|c|c|c|}
\hline Country(ies) & Period & $\begin{array}{l}\text { Unit of } \\
\text { Analysis }\end{array}$ & Author & $\begin{array}{l}\text { Analytical } \\
\text { Method }\end{array}$ & $\begin{array}{l}\text { Expenditure } \\
\text { Components }\end{array}$ & $\begin{array}{l}\text { Summary of } \\
\text { Empirical Findings }\end{array}$ \\
\hline Bolivia & 1996 & Municipalities & $\begin{array}{l}\text { Ajwad and Wodon, } \\
2001\end{array}$ & $\begin{array}{l}\text { Marginal benefit } \\
\text { incidence analysis }\end{array}$ & $\begin{array}{l}\text { Education and basic infrastructure } \\
\text { services }\end{array}$ & $\begin{array}{l}\text { The marginal benefit incidence is } \\
\text { higher for the poor than for the non- } \\
\text { poor in education, but lower in the } \\
\text { case of access to infrastructure } \\
\text { services. }\end{array}$ \\
\hline China & $1970-1997$ & Province & Fan and Hazell, 2001 & $\begin{array}{l}\text { Regression analysis } \\
\text { (system of equations) }\end{array}$ & $\begin{array}{l}\text { Public investments in rural areas } \\
\text { (R\&D, roads, irrigation, education, } \\
\text { electricity, telephone) }\end{array}$ & $\begin{array}{l}\text { R\&D and education have the largest } \\
\text { poverty and productivity impact. For } \\
\text { all public investments, less-favored } \\
\text { areas provide the highest returns. }\end{array}$ \\
\hline $\begin{array}{l}\text { Cross- } \\
\text { country (20) }\end{array}$ & 1976-1999 & Households & $\begin{array}{l}\text { Foster and Szekely, } \\
2001\end{array}$ & $\begin{array}{l}\text { Regression analysis } \\
\text { (various techniques) }\end{array}$ & Government consumption & $\begin{array}{l}\text { Government consumption as a share } \\
\text { of GDP has a negligible effect on } \\
\text { general means but is associated with } \\
\text { income gains for the poorest } \\
\text { individuals. }\end{array}$ \\
\hline $\begin{array}{l}\text { Cross- } \\
\text { country (92) }\end{array}$ & $1950-99$ & Country & $\begin{array}{l}\text { Dollar and Kraay, } \\
2002\end{array}$ & $\begin{array}{l}\text { Regression analysis } \\
\text { (system of equations) }\end{array}$ & $\begin{array}{l}\text { Overall government consumption, } \\
\text { social spending }\end{array}$ & $\begin{array}{l}\text { Overall government spending } \\
\text { negatively related to poverty, but } \\
\text { health and education spending are } \\
\text { insignificant. }\end{array}$ \\
\hline Ethiopia & 2003-2015 & Country & $\begin{array}{l}\text { Agenor, Bayaktar, and } \\
\text { El Aynaoui, } 2004\end{array}$ & $\begin{array}{l}\text { Aggregate } \\
\text { macroframework }\end{array}$ & Infrastructure, health, and education & $\begin{array}{l}\text { Simulated decrease in consumption } \\
\text { spending and reallocation into } \\
\text { investment spending (with higher } \\
\text { increase in infrastructure relative to } \\
\text { education and health) have modest } \\
\text { effects on poverty. }\end{array}$ \\
\hline Ghana & 1999 & Country & $\begin{array}{l}\text { Dabla-Norris and } \\
\text { Matovu, } 2002\end{array}$ & Dynamic CGE & $\begin{array}{l}\text { Primary, secondary, and tertiary } \\
\text { education, and public infrastructure }\end{array}$ & $\begin{array}{l}\text { Increasing primary and secondary } \\
\text { education has significant } \\
\text { macroeconomic and poverty reduction } \\
\text { benefits, even if these come at the } \\
\text { expense of infrastructure investment. }\end{array}$ \\
\hline India & $1970-1995$ & District & Fan and Hazell, 2001 & $\begin{array}{l}\text { Regression analysis } \\
\text { (system of equations) }\end{array}$ & $\begin{array}{l}\text { Public investments in rural areas } \\
\text { (HYV, roads, canal irrigation, } \\
\text { education, electrification) }\end{array}$ & $\begin{array}{l}\text { Roads have the largest poverty and } \\
\text { productivity impact. For all public } \\
\text { investments, less-favored areas } \\
\text { provide the highest returns. }\end{array}$ \\
\hline India & $1957-1997$ & States & $\begin{array}{l}\text { Jha, Biswal, and } \\
\text { Biswal, } 2001\end{array}$ & $\begin{array}{l}\text { Regression analysis } \\
\text { (panel regression) }\end{array}$ & $\begin{array}{l}\text { Education, health, and development } \\
\text { expenditures (poverty eradication } \\
\text { programs, rural sector development, } \\
\text { and infrastructure) }\end{array}$ & $\begin{array}{l}\text { Education, health and development } \\
\text { expenditures reduce poverty. In } \\
\text { particular, expenditure on higher, } \\
\text { university, technical, adult and } \\
\text { vocational educations is more } \\
\text { effective, compared to elementary and } \\
\text { secondary education. }\end{array}$ \\
\hline $\begin{array}{l}\text { Sub-Saharan } \\
\text { Africa }\end{array}$ & 1998-2015 & Country & $\begin{array}{l}\text { Lofgren and } \\
\text { Robinson, } 2004\end{array}$ & Dynamic CGE & $\begin{array}{l}\text { Agriculture, health, education, } \\
\text { transport-communications, social } \\
\text { security, defense, and other }\end{array}$ & $\begin{array}{l}\text { Increased expenditures on agriculture } \\
\text { and transportation and } \\
\text { communications generate modest } \\
\text { economic growth. Increased } \\
\text { investment in health leads to more } \\
\text { rapid growth and significant poverty } \\
\text { reduction. }\end{array}$ \\
\hline Tanzania & 1992 & Country & $\begin{array}{l}\text { Jung and Thorbecke, } \\
2003\end{array}$ & CGE & Education and investment & $\begin{array}{l}\text { Well-targeted education expenditures } \\
\text { can be effective for poverty } \\
\text { alleviation. To maximize benefits, } \\
\text { education spending needs to be } \\
\text { complemented by sufficient public } \\
\text { investment. }\end{array}$ \\
\hline
\end{tabular}


Table 1. Summary of Selected Empirical Studies: Public Expenditure and Poverty (continued)

\begin{tabular}{|c|c|c|c|c|c|c|}
\hline Country(ies) & Period & $\begin{array}{l}\text { Unit of } \\
\text { Analysis }\end{array}$ & Author & $\begin{array}{l}\text { Analytical } \\
\text { Method }\end{array}$ & $\begin{array}{l}\text { Expenditure } \\
\text { Components }\end{array}$ & $\begin{array}{l}\text { Summary of } \\
\text { Empirical Findings }\end{array}$ \\
\hline Thailand & $\begin{array}{l}1986,1990, \\
1994\end{array}$ & Households & Warr, 2003 & $\begin{array}{l}\text { Partial equilibrium } \\
\text { analysis }\end{array}$ & $\begin{array}{l}\text { Education, health, agriculture, and } \\
\text { transportation. }\end{array}$ & $\begin{array}{l}\text { Increased spending on education, } \\
\text { health, and agriculture reduces poverty } \\
\text { while higher share of spending on } \\
\text { transportation increases poverty. }\end{array}$ \\
\hline Uganda & $\begin{array}{l}1992,1995, \\
1999\end{array}$ & District & $\begin{array}{l}\text { Fan, Zhang, and Rao, } \\
2004\end{array}$ & $\begin{array}{l}\text { Regression analysis } \\
\text { (system of equations) }\end{array}$ & $\begin{array}{l}\text { Public investments in rural areas } \\
\text { (Agricultural research and extension, } \\
\text { low-grade and high-grade roads, } \\
\text { education, and health) }\end{array}$ & $\begin{array}{l}\text { Research has the largest poverty and } \\
\text { rural productivity impact. Impact of } \\
\text { low-grade road larger than high-grade } \\
\text { road. Spening in poor regions } \\
\text { contribute the most to poverty } \\
\text { reduction. }\end{array}$ \\
\hline Vietnam & $1993-2000$ & Province & $\begin{array}{l}\text { Fan, Huong, and } \\
\text { Long, } 2003\end{array}$ & $\begin{array}{l}\text { Regression analysis } \\
\text { (system of equations) }\end{array}$ & $\begin{array}{l}\text { Public investments in rural areas } \\
\text { (Agricultural research, roads, } \\
\text { irrigation, education, electricity, } \\
\text { telephone) }\end{array}$ & $\begin{array}{l}\text { Research has the largest poverty and } \\
\text { productivity impact. }\end{array}$ \\
\hline Zambia & 1995 & Country & $\begin{array}{l}\text { Jung and Thorbecke, } \\
2003\end{array}$ & CGE & Education and investment & $\begin{array}{l}\text { Well-targeted education expenditures } \\
\text { can be effective for poverty } \\
\text { alleviation. To maximize benefits, } \\
\text { education spending needs to be } \\
\text { complemented by sufficient public } \\
\text { investment. }\end{array}$ \\
\hline
\end{tabular}

Sources: As indicated.

To conclude the review of the empirical literature, we mention additional strands of work that investigate other dimensions of the public spending and poverty link such as complementarities in public spending and, combined benefit incidence. ${ }^{28}$

Complementarities. Complementarities between government interventions may come in two general forms: some interventions are enhanced by the presence of other interventions; some interventions are mitigated by the presence of other interventions. First, the benefits of higher expenditure on a particular sector may not be fully realized unless expenditure on other sectors is increased. For example, Fay and others (2003) find that better access to basic infrastructure services (water and sanitation) has an important role in improving child health outcomes. Similarly, van de Walle (1995) suggests that education investment may enhance the marginal impact of irrigation projects (1995). A related point is the necessity of sufficient human capital to realize the benefits of infrastructure investments. For example, the ADB (2002) finds that the ability of the poor to make significant economic use of roads depends on their asset base, their skills, etc. ${ }^{29}$.

${ }^{28}$ Admittedly, there is yet further work that investigates other important facets of the link between public expenditure and poverty. As it is not the objective of this paper to give a complete account of all this work we are not discussing this further. Nonetheless, there is an abundant literature on the role of governance on the effectiveness of public expenditure.

${ }^{29}$ There are many other examples of this type of complementary documented in the literature. For example, Deininger and Okidi (2003) use micro-level survey and panel-data evidence from Uganda spanning 1992-2000 and find that the benefits of education and health care for growth and poverty reduction depend on complementary investments in electricity and other infrastructure, and reductions in civil strife. 
Combined incidence. While we have emphasized the understanding of the different options in expenditure policy choices, tax policy and cost recovery may also have important implications for poverty reduction. User charges for education and health services, for example, tend to be regressive and may restrict poorer household's access to critical social services. A strand of the benefit incidence literature has attempted to gauge the net impact of government interventions, combining both the expenditure and tax incidence to estimate the net incidence of fiscal policy. ${ }^{30}$ Despite its limitations, net incidence analysis nonetheless represents an important improvement over simple expenditure incidence analysis. ${ }^{31}$

\section{CONCLUSIONS AND IMPLICATIONS}

- The impact of public spending on common economic goals such as growth, equity and poverty reduction is difficult to assess because of the complex chain of linkages, the time lags involved and the interdependence among the goals. Both initial conditions and institutional capabilities have an important influence on the effectiveness of transmission mechanisms and must be factored into country-specific policy recommendations.

- Nevertheless, understanding these linkages is key to good public expenditure policy. The absence of an appropriate conceptual framework to investigate the link between public spending and its impact on growth and poverty reduction is a weakness that has contributed to ad hoc approaches to public expenditure policy. The recent, donor-led emphasis on identifying and increasing spending on categories of expenditure presumed to be "pro-poor" reflects the lack of such a theoretical framework.

- The main contribution of this paper is to propose a conceptual framework within which questions about broad economic objectives, including growth and poverty reduction, and the appropriate policy instruments (including the appropriate composition of public spending) can be studied. The framework suggests a hierarchy of issues to be addressed sequentially prior to focusing on particular questions regarding the contribution of public spending to poverty reduction.

- For any given objective, the development strategy is a point of reference that is country specific. But it also provides an important point of reference against which to evaluate the consistency of public policies relative to the dynamic (growth and poverty reduction) aspects of the strategy.

- Public economics suggests evaluating the policy framework in terms of the efficiency (market failure) or equity rationale for public policy intervention. While important and necessary, these principles do not provide a sufficient basis to understand and evaluate the dynamic effects of public spending on growth and poverty.

\footnotetext{
30 See for example Toye and Jackson (1996).

31 See Whalley (1987) on the improper measurement of consumer surplus. In addition, as typically implemented, net fiscal incidence analysis focuses only on the static incidence and not on net benefits accumulated over time (see, for example, World Bank 1990).
} 
- Where governments justify their interventions in terms of growth and poverty reduction objectives such policies should be subjected to rigorous evaluation in terms of their effectiveness in achieving the goals of the stated development strategy.

- The tradeoffs between social expenditure and infrastructure expenditure, or between policy interventions in general, need to be understood from a dynamic perspective. We do not have all the parameters for understanding all the dynamic interrelationships and cumulative effects, but available empirical tools would allow us preliminary insights into the nature of immediate and lagged effects of expenditure, complementarities, externalities, combined fiscal incidence, and thresholds. The use of such tools and techniques would enable this framework to be used to improve the quality of public policy advice to governments seeking to accelerate growth, improve equity and reduce poverty.

Operational Implications for the World Bank.

There are clear operational implications for the Bank's analytical work that follow from these conclusions.

- First, it suggests that the analytical work undertaken by the World Bank in advising governments on their development (PRSP) strategies such as Development Policy Reviews, Country Economic Memoranda and Poverty Assessments should be better integrated with work on Public Expenditure Reviews along the lines suggested by the proposed framework to enable our policy advice on public spending to better link growth, equity, poverty and public expenditure. ${ }^{32}$ This might seem like an obvious point but actual practice suggests that this good practice is often not applied.

- Second, it suggests that the Bank should invest in analytical work that clarifies the expenditure options available to governments to stimulate growth and development. The identification of binding constraints to growth and an assessment of the role of public spending in addressing those constraints would be one avenue to pursue in advising on expenditure composition. In many low-income countries, the Bank has undertaken PERs and Poverty Assessments without the corresponding investment in analytical work on growth and development. This has contributed to the impression of superficiality in the Bank's advice on public expenditure allocation and to adoption of simplistic rules of thumb regarding the growth or poverty impact of specific expenditure.

- Third, there is in general a paucity of empirical work on the impact of the composition of public spending on growth, equity and absolute poverty. Expenditure allocations need to be examined with respect to their alignment with a country's growth strategy or the PRSP as well as empirical validation of their

\footnotetext{
32 This is not to suggest the preparation of a massive physically "integrated" report but to recommend that country teams ensure that the economic and sector work (ESW) program ensure sufficient analytical attention to the development strategy and to link those findings to policy analysis, such as analysis of the spending choices represented by the budget in terms of the development objectives.
} 
contribution over time to growth, equity and poverty reduction. It will be important to initiate more country specific analytical work (supplemented as appropriate by cross-country studies) on these issues.

- Fourth, to be balanced, analysis of the budget in PERs should be comprehensive and not limited to specific "in-favor" sectors. This would limit the risk of periodic swings in coverage wherein a bias towards spending on social sectors is replaced by a bias towards the infrastructure or rural development sectors, based on current donor views of priorities.

- Fifth, there is a case to be made for taking a public finance perspective (i.e. both the revenue raising and spending aspects of the budget) rather than just a public expenditure perspective. Benefit incidence may often be insufficient to gauge the pro-poor stance of the budget. Thus net fiscal incidence analysis, which takes account of both the revenue raising and the expenditure impact, may be more appropriate.

- Finally, evaluation of the role of regulatory policy and public infrastructure in stimulating private investment and private sector activity would also be possible and necessary within this framework.

There is, in our view, a significant agenda of work that needs to be undertaken in this area that will be a valuable contribution to development policy. In particular, we feel that there is neglected middle ground between the disciplines of public economics policy and the theory of economic growth that requires attention to link the two disciplines. This paper is intended to provoke a discussion both about the nature of such work and its sequencing and to stimulate the first steps in that regard. 


\section{REFERENCES}

Agenor, Pierre Richard, Nihal Bayaktar, and Karim El Aynaoui, 2004, "Roads Out of Poverty? Assessing the Links Between Aid, Public Investment, Growth, and Poverty Reduction?" mimeo (Washington: The World Bank).

Ajwad, M. I., and Q. Wodon, 2001, "Do Local Governments Maximize Access Rates to Public Services Across Areas? A Test Based on Marginal Benefit Incidence Analysis," mimeo (Washington: The World Bank).

Asian Development Bank, 2002, "Impact of Rural Roads on Poverty Reduction: A Case Study Based Analysis," (Manila: ADB Operations Evaluation Department).

Atkinson, Paul and Paul van den Noord, "Managing Public Expenditure: Some Emerging Policy Issues and a Framework for Analysis," OECD Economics Department Working Paper No. 285, February 2001.

Baldacci, Emanuele, and Benedict Clements, and Sanjeev Gupta, 2003, "Using Fiscal Policy to Spur Growth," Finance \& Development, December: 28-31.

Bannerjee, Abhijit and Ruimin He, 2003, "The World Bank of the Future”, BREAD Working Paper No. 13.

Belli, Pedro, 1996, "Is economic analysis of projects still useful?” Policy Research Paper No. 1689 (Washington: The World Bank).

Bose, Niloy, M. Emranul Haque, and Denise R. Osborn, 2003, "Public Expenditure and Economic Growth: A Disaggregated Analysis for Developing Countries," mimeo.

Bourguignon, Francois, and others, 2004, "MAMS - Maquette for MDGs Simulation," mimeo (Washington: The World Bank).

Cairncross, Sandy, 1992, Sanitation and Water Supply: Practical Lessons from the Decade (Washington: The World Bank and UNDP).

Canning, David and Esra Bennathan, 2000, "The Social Rate of Return on Infrastructure Investments," Working Paper No. 2390 (Washington: The World Bank).

Collier, Paul, Stefan Dercon and John Mackinnon, 2002, "Density versus Quality in Health Care Provision: Using Household Data to Make Budgetary Choices in Ethiopia," World Bank Economic Review, Vol. 16, No. 3: pp. 425-448.

Corbacho, Ana and Gerd Schwartz, "Mexico: Experiences with Pro-Poor Expenditure Policies,” IMF Working Paper No. 02/12 (Washington: International Monetary Fund). 
Dabla-Norris, Era and John M. Matovu, 2002, "Composition of Government Expenditures and Demand for Education in Developing Countries," International Monetary Fund Working Paper No. 02/78 (Washington: International Monetary Fund).

Deaton, Angus, 2003, “Health, Inequality, and Economic Development," Journal of Economic Literature, Vol. 41, No. 1 (March): pp. 113-58.

Dehn, Jan and Ritva Reinikka, and Jakob Svensson, 2003, "Survey Tools for Assessing Performance in Service Delivery," in Bourguignon, Francois and Luiz A. Pereira da Silva, eds., The impact of economic policies on poverty and income distribution: evaluation techniques and tools (Washington: The World Bank).

Demery, Lionel, 2003, “Analyzing the Incidence of Public Spending,” in Bourguignon, Francois and Luiz A. Pereira da Silva, eds., The impact of economic policies on poverty and income distribution: evaluation techniques and tools (Washington: The World Bank).

Devarajan, Shantayanan, Vinaya Swaroop, and Heng-fu Zou, 1996, "The Composition of Public Expenditure and Economic Growth," Journal of Monetary Economics, Vol. 37: pp. 313-344.

Devarajan, Shantayanan, and others, 2001, "Guidelines for the World Bank's Work on Public Expenditure Analysis and Support (including PERs)," mimeo (Washington: The World Bank).

Devarajan, S., L. Squire, and S. Suthiwart-Narueput, 1995, "Reviving Project Appraisal at the World Bank," Policy Research Paper No. 1496 (Washington, The World Bank).

Dollar, David and Aart Kraay, 2002, "Growth Is Good for the Poor," Journal of Economic Growth Vol. 7, No. 3 (September): 195-225

Duncan, Ron and Steve Pollard, 2002, "A Framework for Establishing Priorities in a Country Poverty Reduction Strategy,” ERD Working Paper Series No. 15 (Manila: Asian Development Bank). Reprinted in Christopher Edmonds and Sara Medina, eds., 2002, Defining an Agenda for Poverty Reduction (Manila: Asian Development Bank), pp. 91-107.

Fan, Shenggen , and Peter Hazell, 2001, "Returns to Public Investments in the Less-favored Areas of India and China," American Journal of Agricultural Economics, Vol. 83, No. 5: pp. 1217-1222

Fan, Shenggen, Pham Lan Huong, and Trinh Quang Long, 2003, "Government Spending and Poverty Reduction in Vietnam," mimeo (Washington: International Food Policy Research Institute).

Fan, Shenggen, Xiaobo Zhang, and Neetha Rao, 2004, "Public Expenditure, Growth, and Poverty Reduction in Rural Uganda," IFPRI Discussion Paper No. 4 (Washington: International Food Policy Research Institute). 
Fay, Marianne, Danny Leipziger, Quentin Wodon, and Tito Yepes, 2003, “Achieving the Millennium Development Goals: The Role of Infrastructure," Policy Research Paper No.: 2390 (Washington: The World Bank).

Foster, J. and M. Székely, 2001 "Is Growth Good for the Poor?: Tracking Low Incomes Using General Means,” RES Working Paper Series No. 453 (Washington: Inter American Development Bank Research Department).

Ferroni, Marco and Ravi Kanbur, 1992, "Poverty-Conscious Restructuring of Public Expenditure," in Economic Reform in sub-Sabaran Africa, Ajay Chhibber and Stanley Fischer, eds. (Washington: The World Bank).

Foster, Mick, Adrian Fozzard, Felix Naschold and Tim Conway, 2002, "How, When and Why Does Poverty Get Budget Priority? Poverty Reduction Strategy and Public Expenditure Reform in Five African Countries," Working Paper 168 (London: Overseas Development Institute).

Fozzard. Adrian, 2001, “The Basic Budgeting Problem: Approaches to Resource Allocation in the Public Sector and their Implications for Pro-Poor Budgeting," ODI Working Paper No. 147 (London: Overseas development Institute).

Fozzard, Adrian, Malcolm Holmes, Jeni Klugman, and Kate Withers, 2002, "Public Spending," in A Sourcebook for Poverty Reduction Strategies, Jeni Klugman, ed. (Washington: The World Bank).

Gomanee, Karuna , Sourafel Girma and Oliver Morrissey, 2003, "Aid, Public Spending and Human Welfare: Evidence from Quantile Regressions," CREDIT Research Paper No. 03/13, University of Nottingham.

Gomanee, Karuna, Oliver Morrissey, Paul Mosley and Arjan Verschoor, 2003, “Aid, ProPoor Government Spending and Welfare," CREDIT Research Paper No. 03/03, University of Nottingham.

Gomanee, K. and O. Morrissey, 2002, "Evaluating aid effectiveness against a povertyreduction criterion," paper prepared for the DESG conference, University of Nottingham, April.

Gupta, Sanjeev, Benedict Clements, Emanuele Baldacci, and Carlos Mulas-Granados, 2003, "Fiscal Policy, Expenditure Composition, and Growth in Low-Income Countries," Journal of International Money and Finance, forthcoming.

Hemming, Richard, 1991, "Public Expenditure and Resource Allocation," in Public Expenditure Handbook, Ke-young Chu and Richard Hemming, eds. (Washington: International Monetary Fund).

Hentschel, Jesko, 2002, “Pro-Poor Spending,” PREM Learning Week 2002 presentation. 
Herrera, Santiago and Fernando Blanco, 2004, "The Quality of Fiscal Adjustment and the Long Run Growth Impact of Fiscal Policy in Brazil," Draft paper, World Bank.

International Monetary Fund, 1995, "Unproductive Public Expenditures: A Pragmatic Approach to Policy Analysis," Pamphlet No. 48 (Washington: International Monetary Fund).

IMF Independent Evaluation Office (IEO), 2004, Report on the Evaluation of Poverty Reduction Strategy Papers (PRSPs) and The Poverty Reduction and Growth Facility (PRGF) (Washington: International Monetary Fund). http://www.imf.org/External/NP/ieo/2004/prspprgf/eng/index.htm.

International Monetary Fund and World Bank, 2003, "Heavily Indebted Poor Countries (HIPC) Initiative: Status of Implementation," (Washington: International Monetary Fund). http://www.imf.org/external/np/hipc/2003/status/091203.htm.

Jha, Raghbendra, Bagala Biswal, and Urvashi D. Biswal, 2001, "An Empirical Analysis of the Impact of Public Expenditures on Education and Health on Poverty in Indian States," mimeo.

Jung, Hong-Sang, and Erik Thorbecke, 2003, “The Impact of Public Education Expenditure on Human Capital, Growth, and Poverty in Tanzania and Zambia: A General Equilibrium Approach," Journal of Policy Modeling Volume 25, No. 8 (November): pp. 701-725.

Kawachi, Ichiro, Bruce P. Kennedy, and Richard G. Wilkinson, 1999, The society and population bealth reader: Volume 1: Income inequality and health (New York: New Press).

Killick, Tony, 2004, "Politics, Evidence, and the New Aid Agenda," Development Policy Review, Vol. 22, No. 1: pp. 5-29.

Lanjouw, Peter and Martin Ravallion, 1999, "Benefit Incidence, Public Spending Reforms, and the Timing of Program Capture," World Bank Economic Review, Vol. 13, No. 2: pp. 257-73.

Larsen, Theo Ib and Martin Rama, 2003, “An Empirical Assessment of Vietnam's Public Investment Program," cited in Vietnam Development Report 2004.

Lipton, Michael and Martin Ravallion, 1995, "Poverty and Policy," in Handbook of Development Economics, Vol. 3B, Hollis Chenery, ed. (Amsterdam: Elsevier).

Lofgren, Hans and Sherman Robinson, 2004, Public Spending, Growth, and Poverty Alleviation in Sub-Saharan Africa: A Dynamic General Equilibrium Analysis," mimeo (Washington: International Food Policy Research Institute). 
Lopez, Ramon, Vinod Thomas, and Yan Wang, 1998, “Addressing the Education Puzzle: The Distribution of Education and Economic Reform," Policy Research Paper No. 2031 (Washington: The World Bank).

Mackinnon, John and Ritva Reinikka, 2000, "Lessons from Uganda on Strategies to Fight Poverty," Policy Research Paper No.2440 (Washington: The World Bank).

Mooji, Jos, and S. Mahendra Dev, 2004, "Social Sector Priorities: An Analysis of Budgets and Expenditures in India in the 1990s," Development Policy Review, Vol. 22, No. 1: pp. 97-120.

Mosley, Paul and John Hudson, 2001, “Aid, Poverty Reduction and the 'New Conditionality,"' mimeo.

Musgrave, R.A., 1985, “A Brief History of Fiscal Doctrine,” in A.J. Auerbach and M. Feldstein, eds., Handbook of Public Economics (Amsterdam: North Holland).

OECD DAC, 1999, DAC Scoping Study of Donor Poverty Reduction Policies and Practices (Paris: OECD).

Perotti, Roberto, 2002, “ Public Spending on Social Protection in Columbia: Analysis and Proposals," mimeo.

Pradhan, Sanjay, 1996, "Evaluating Public Spending: A Framework for Pubic Expenditure Reviews," World Bank Discussion Paper No. 323 (Washington: The World Bank).

Ravallion, Martin, 2003, “On Measuring Aggregate "Social Efficiency” Policy Research Paper No. 3166 (Washington: The World Bank).

Roseboom, Johannes, 2002, “Underinvestment in Agricultural R\&D Revisited," Quarterly Journal of International Agriculture, Vol. 41, No. 4 (2002): pp. 297-316

Schneider, A., 2003, "Who Gets What From Whom? The Impact of Decentralisation on Tax Capacity and Pro-Poor Policy," IDS Working Paper 179 (Sussex: Institute of Development Studies, University of Sussex).

Schultz, T. Paul., 2002, "Wage Gains Associated with Height as a Form of Health Human Capital," American Economic Review, Vol. 92, No. 2 (May): pp. 349-53.

1997, "Assessing the Productive Benefits of Nutrition and Health: An Integrated Human Capital Approach,” Journal of Econometrics, Vol. 77, No. 1 (March): pp. 141-58

Self, Sharmistha and Richard Grabowski, 2004, "Does education at all levels cause growth? India, a case study," Economics of Education Review, Vol. 23: pp. 47-55.

Swaroop, Vinaya, 1999, "Public Expenditure Reviews: Progress and Potential," PREM Notes No. 20 (April). 
Toye, John and Carl Jackson, 1996, "Public Expenditure Policy and Poverty Reduction," IDS Bulletin, Vol. 27, No. 1: pp. 56-66.

Walker, Mabel L., 1930, Municipal Expenditures (Baltimore: Johns Hopkins Press), reprinted 1983.

Warr, Peter, 2003, "Fiscal Policies and Poverty Incidence: The Case of Thailand," Asian Economic Journal, Vol. 17, No. 1: pp. 27-44.

Williamson, Tim and Sudharshan Canagarajah, 2003, "Is there a place for Virtual Poverty Funds in Pro-Poor Public Spending Reform? Lessons from Uganda's PAF," Development Policy Review, Vol. 21, No. 4: pp. 449-480.

Wilkinson, Richard G., 1992, "Income distribution and life-expectancy," British Medical Journal, No. 304: pp. 165-68.

World Bank, 2003a, African Development Indicators (Washington: The World Bank). , 2003b, The Heavily Indebted Poor Countries (HIPC) Debt Initiative: An OED Review, Report No. 25160 (Washington: The World Bank).

,2003c, Tanzania: Managing public expenditures for poverty reduction report on fiscal developments and public expenditure management issues, Report No. 26807 (Washington: The World Bank).

, 2002, Uganda: Public expenditure review: report on the progress and challenges of budget reforms, Report No. 24882 (Washington: The World Bank).

, 2001a, Ethiopia: Focusing Public Expenditures on Poverty Reduction, Report No. 23351 (Washington: The World Bank).

, 2001b, Zambia Public expenditure review: public expenditure, growth and poverty - a synthesis, Report No. 22543 (Washington: The World Bank).

, 2000, The effectiveness of the World Bank's poverty reduction strategy: an evaluation, Report No. 20145 (Washington: The World Bank).

, 1998, The impact of public expenditure reviews: an evaluation, Report No. 18573

(Washington: The World Bank).

, 1995, The social impact of adjustment operations, Report No. 14776 (Washington: The World Bank).

, 1993, Poverty Reduction Handbook (Washington: The World Bank).

1988, World Development Report 1988 (Washington: The World Bank). 
World Bank et al, 2004, Vietnam Development Report (Hanoi: Vietnam Development Information Center). 


\section{Appendix I. Empirical Evaluation of Pro-Poor Fiscal Stance: Selected Studies}

As noted in the main text, academic studies have themselves consistently used social spending or spending on the education and health sectors as proxy for pro-poor spending. The pro-poor stance of the budget is then assessed based on the relative shares of public spending on education and health care in the overall government budget (e.g., Mooji and Dev, 2004). Using a similar measure, Schneider (2003) determines whether decentralization leads to higher pro-poor spending.

\begin{tabular}{|c|c|c|c|c|c|}
\hline Author & Coverage & Period & Method & Pro-Poor Measure & Empirical Findings \\
\hline Schneider 2003 & 68 Countries & 1996 & Regression analysis & Social sector spending & $\begin{array}{l}\text { Political decentralization has a negative impact } \\
\text { and adminstrative decentralization a positive } \\
\text { impact on propoor spending. }\end{array}$ \\
\hline $\begin{array}{l}\text { Gomanee and } \\
\text { Morrissey } 2002\end{array}$ & 57 Countries & $1980-98$ & Regression analysis (panel) & $\begin{array}{l}\text { Expenditure on social services, } \\
\text { education and health }\end{array}$ & $\begin{array}{l}\text { Public social expenditure mediates the positive } \\
\text { effects of aid flows on poverty levels. }\end{array}$ \\
\hline $\begin{array}{l}\text { Gomanee, Girma } \\
\text { and Morrissey } 2003\end{array}$ & 38 Countries & 1980-98 & $\begin{array}{l}\text { Regression analysis } \\
\text { (quantile) }\end{array}$ & $\begin{array}{l}\text { Expenditure on sanitation and } \\
\text { housing services, education and } \\
\text { health services }\end{array}$ & $\begin{array}{l}\text { Aid can affect welfare via public expenditure, } \\
\text { and this effect tends to be greater in countries } \\
\text { with lower welfare. }\end{array}$ \\
\hline $\begin{array}{l}\text { Mooij and Dev } \\
2004\end{array}$ & India & 1990-02 & Descriptive statistics & Social sector spending & $\begin{array}{l}\text { Documents a shift in spending, within the } \\
\text { social sectors, from income and employment } \\
\text { programmes to human development } \\
\text { programmes. Concludes that there is an urgent } \\
\text { need to increase social spending. }\end{array}$ \\
\hline $\begin{array}{l}\text { Corbacho and } \\
\text { Schwartz } 2001\end{array}$ & Mexico & 1980-02 & $\begin{array}{l}\text { Descriptive statistics, } \\
\text { benefit incidence analysis }\end{array}$ & $\begin{array}{l}\text { Expenditure on education, } \\
\text { health, social security and other } \\
\text { social expenditure programs } \\
\text { (including targeted spending for } \\
\text { human capital devt, basic social } \\
\text { infrastructure, and productivity) }\end{array}$ & $\begin{array}{l}\text { Primary education spending is progressive, } \\
\text { considerable access improvement in health, no } \\
\text { significant impact from social security, } \\
\text { promising results from some recent initiatives } \\
\text { that target specific groups. }\end{array}$ \\
\hline $\begin{array}{l}\text { Mosley and } \\
\text { Hudson } 2001\end{array}$ & 57 Countries & 1994-98 & Regression analysis & $\begin{array}{l}\text { Expenditure on education, social } \\
\text { services, and agriculture }\end{array}$ & $\begin{array}{l}\text { Aid raises pro-poor spending in poor } \\
\text { countries but not in middle-income countries. }\end{array}$ \\
\hline
\end{tabular}

In some cases, simple first-stage cross-country regressions of the poverty headcount (or some other measure of poverty) on each of the major expenditure categories, including education and health care, are estimated, to determine which expenditures are "pro-poor" (e.g., Gomanee, Girma, and Morrissey 2003). Without taking into account the complexities discussed in the main text, these simple, bivariate regressions provide some evidence that education and health care spending are pro-poor. In the second-stage, the statistical relationship between, for example, aid flows and pro-poor expenditure items is evaluated. 


\title{
Appendix II. A Brief Survey of Related Literature
}

\author{
General Guidelines on Expenditure Allocation
}

Devarajan et al (2001) present a way to evaluate expenditure composition with respect to the principles of welfare economics. In particular, they pose three questions as a way of applying those principles: First, what is the rationale for public intervention?

Second, what is the best instrument for public intervention (public provision, subsidies, etc.? Third, what is the fiscal cost of public provision (assuming it is the best instrument) and how does it compare with other expenditures that survive the test of the first two questions. With respect to the first question, the rationale is either market failure or redistribution. For documenting the degree of market failure, they suggest that quantitative estimate of the degree of crowding out of the private sector, for example, is helpful for evaluating public spending. For evaluating the redistributive objective of public intervention, they suggest that the benefit incidence analysis of public expenditure is valuable.

Fozzard, Holmes, Klugman and Withers (2002) present a similar, three-step framework for deciding when and how governments should intervene: First, determine the rationale for public intervention. Second, decide on the appropriate instrument to offset market failures or improve distribution outcomes. Third, assess expenditure options. For evaluating expenditure options in general, they survey the available technical tools for guiding policy choices, including cost-effectiveness analysis, multi-criteria analysis, and social cost-benefit analysis. Without providing details on how this could be properly carried out, they also suggest an "overall evaluation," to determine which public interventions, compared with other interventions, have made a difference. In the absence of quantitative evaluation results in a given country, they suggest two short-term resources: (a) the existing body of experience on how programs work in a country and (b) experiences in other countries with similar characteristics.

Similarly, Pradhan (1996) notes that there has been no systematic attempt in the literature to evaluate methodologies for allocation decisions and offer guidelines for policy choices. He reviews the growing literature on the cross-country analyses of expenditure allocation and growth and concludes that "they are unlikely to provide useful implication" (92). He proposes, instead, that the same three (3) criteria applied to allocation decisions within sectors be applied to decisions across sectors: (i) role of government versus the private sector; (ii) cost-benefit analysis of input-output packages; and (iii) impact on the poor.

The first criterion (i) implies that resources should be channeled to programs that the private sector cannot provide. The second criterion (ii) requires information on the rate of return to various programs. Pradhan (1996) acknowledges that the principal problem lies in the valuation of benefits in selected sectors (health, education, and defense). In light of these difficulties, he suggests a "three-step analysis." First, identify alternative combinations of expenditure allocation and their corresponding outcomes. Second, evaluate tradeoffs between these alternative combinations. He shows hypothetical examples of rates of return and input-outcome relationships across sectors as an illustration. Third, alternative 
combinations can be subject to voting through the budget process, where households, for example, lobby for packages they are willing to pay for.

What is the consensus on the usefulness of quantitative techniques for guiding resource allocation? Some existing guidelines are less confident about the value of existing empirical tools. For example, the World Bank's Poverty Reduction Handbook (World Bank 1993) notes that some sectors lend themselves more easily to economic cost-benefit analysis. For others, the criteria are less well defined. In theory the allocation of resources across programs should be based on the highest returns. In practice, a full economic analysis will not be possible except for a few sectors. There is then a large premium on professional judgment, based on sectoral and country expertise. The World Bank Bank's review of PERs also confirms that, in practice, there is no optimal allocation of resources (Swaroop 1999) and that the careful design and implementation of expenditure priorities needs to be conducted country by country.

Similarly, the World Development Report on Public Finance in Development (World Bank 1988) notes that "no clear techniques exist to guide inter-sectoral choices," although identifying bottlenecks in the economy and comparing rates of returns to alternative programs may provide guidance. The Report also finds that allocation decisions are inevitably based on intuitive judgments, with recognition of the need for overall balance between sectors.

With respect to public spending for poverty reduction, the Report identifies four (4) characteristics of spending that determine the efficiency and effectiveness of expenditure, representing a pragmatic approach to setting strategic priorities. First, the unit cost of the service per beneficiary. The report suggests that that basic low-cost services are likely to be of most help to the poor. Such schemes are both affordable by definition and self-targeting. Second, location. Subsidies are unlikely to reach the poorest groups if they are provided exclusively in urban areas. Third, a program's ability to reach the informal sector. And fourth, an explicit focus in a program's design on employment and poverty alleviation (e.g., labor-intensive rural works program).

The IMF (1995) also presents a pragmatic approach for guiding expenditure allocation. In reviewing the concept of "unproductive public expenditures," the IMF identifies some pragmatic guidelines for the analysis of economic components of spending (e.g., general versus targeted subsidy, wage versus non-wage) and the functional components of spending (e.g., primary versus tertiary education). They also suggest the following additional steps for identifying unproductive spending: focus on big-ticket items to identify white elephant projects; comparison of functional and economic classification of spending between countries with the same level of development and in the same region; analysis of overall and sectoral employment to identify shortages in skill or overstaffing by level; examining institutional arrangements to identify unproductive outlays (e.g., extra-budgetary funds and quasi-fiscal activities of the central bank.

Two conclusions are suggested by the above review: one, that the guidelines do not go very far in identifying methodologies for defining pro-poor expenditure. In general, the emphasis is on well established principles of public economics - to identify interventions that address market failures and inefficiencies. To the extent that the guidelines discuss the 
equity objective it is to refer to established methodologies such as benefit incidence analysis, to "professional judgment" and some principles for targeting the poor. Two, to the extent that there is reference to the impact of public spending on the poor, there is no explicit consideration of the short versus the long term, nor on the direct versus indirect, impact on poverty.

\section{Perspectives on Pro-Poor Expenditure Allocation}

There are a number of recent perspectives on expenditure allocation options, with poverty reduction as an explicit target, that do begin to pose the question in terms of the dynamics of poverty reduction.

Ferroni and Kanbur (1992) develop a framework for public expenditure restructuring taking into account both human resource interactions and multidimensionality of the standard of living. The framework allows for the estimation of opportunity cost in terms of poverty reduction of allocating a marginal dollar to an intervention or program. "Public expenditure restructuring," in this context, means reallocating resources between social expenditures and what they call "productive" expenditure, to maximize the standard of living. Ferroni and Kanbur (F-K, hereafter) show that the choice depends on the total welfare effects working through both basic needs and income mechanisms. They make a distinction between direct expenditure (expenditure in the primary sector in which one seeks to obtain improvements) and indirect expenditure (income-enhancing expenditure). The analytical results imply that there is a case for a combination of both "direct" and "indirect" spending. To analyze the poverty-alleviation impact of spending, they identify three sets of parameters that are critical: (a) weights attached to components of the standard of living; (b) estimates of the link between spending and achievements along dimensions of the standard of living; and (c) the benefit incidence of public spending.

The importance of accounting for both the direct and indirect effects of public spending is emphasized by other authors. For example, Mackinnon and Reinikka (2000) drawing from the work of Stern and Dreze (1990) note than the standard method of determining expenditure priorities is by comparing rates of return. Though in practice often neglected, several aspects should be included in such calculations - these include income distributional effects, the substitutions between public and private sectors, and an estimate of external effects. Including these dimensions is particularly critical assessing priorities for poverty reduction. Mackinnon and Reinikka (2000) cite, as an example, tertiary education which does little for poverty reduction directly but may have significant indirect benefits for poverty reduction if graduates contribute to better service provision, remit their income to poor households, or contribute to local communities. But estimates of such externalities are not readily available. Because of the complexities of benefit valuation, allocation decisions again inevitably depend on judgment.

Duncan and Pollard (2002) present a more comprehensive framework within which to think about relative priorities in planned intervention in support of poverty reduction. They identify the building blocks toward the goal of poverty reduction and the corresponding constraints faced along the way. The building blocks include, in order of priority, (a) civil and social order; (b) institutional rules and regulation; (c) good governance; (d) effective markets; (e) pro-poor investment; and (f) pro-poor growth and poverty 
intervention. Without these building blocks in place, Duncan and Pollard suggest that there will be no growth in incomes. For example, investment projects in countries with no civil and social order have historically yielded dismal results.

The OECD (1999) reviews the lessons of experience on what works and what does not work in poverty reduction. It identifies three (3) issues generally regarded as critical: (i) the choice of the appropriate level of targeting; (ii) encouraging participation; and (iii) factors affecting sustainability. It reviews the pros and cons of targeted intervention; notes the "clear and demonstrable" benefits of stakeholders being in a position to influence the design and implementation of the intervention, while acknowledging the significant opportunity costs of participation for poor people; and lists rules for improving the sustainability of povertyfocused projects.

\section{Typologies of Pro-Poor Interventions}

While acknowledging that there is no easy way to define "pro-poor spending," Hentschel (2002) offers three alternative definitions: (i) spending that benefits the poor more than the non-poor; (ii) spending that actually reaches the poor; and (iii) spending that has an impact on the welfare of the poor over time. The merit of these definitions is that they begin to make explicit the concept of pro-poor, distinguishing between the relative and absolute impact on the poor and the long-term impact on poverty. Secondly, they implicitly underline the importance of empirical verification of the impact of public spending on the target group, using analytical techniques such as benefit incidence, service delivery surveys and expenditure tracking.

It is also important to acknowledge that the choice of public intervention must also take account of the nature of poverty being addressed. In a review of the social impact of its adjustment operations, the World Bank (1995) suggests that it is useful to distinguish between transient poverty and chronic poverty. Public expenditure policies are then designed differently depending on the nature of poverty being addressed. For example, with respect to transient poverty (poverty associated with abrupt changes in economic conditions), short run public programs (public relief, food aid, severance pay) may be appropriate. In the case of chronic poverty, two (2) sets of public interventions are appropriate: the first increases the productivity of the poor; the second provides a safety net to those unable to participate in the economy.

Lipton and Ravallion (1995: 2623) present a framework for classifying alternative interventions. While their framework is based on programs that alter inputs into rural production and thus reduce chronic rural poverty, the classification is potentially useful. In their framework, interventions alter choice about inputs-land, human capital, and creditand potentially raise incomes among the poor. In each case, the poor can gain from seven (7) types of interventions that affect inputs by raising input volumes, improving factor productivity, or by altering prices. The interventions include (1) a rise in resource availability; (2) redistribution of resources; (3) a combination of (1) and (2); (4) distribution-neutral enhancement of factor productivity; (5) poor-oriented enhancement of productivity;

(6) price alteration of inputs bought by the poor; and (7) price alteration of outputs produced by the poor. 
For interventions intended to reach the poor, Pradhan (1996) distinguishes between universal programs (or broad targeting) and narrow targeting. The first provides program accessible to all groups while the second actively targets benefits to the poor while excluding the non-poor. Pradhan emphasizes that targeting be seen as a potential instrument and not as an objective. Thus in many developing countries where poverty is widespread and administrative capacity is low, a combination of broad and narrow targeting will be required.

\section{Some Practical Constraints}

Country experiences with pro-poor expenditure policy also suggest that there are important resource and informational constraints in the proper identification and implementation of pro-poor interventions. Mackinnon and Reinikka (2000) review Uganda's experience with the selection of its package of universal basic services and suggest that the most difficult aspect is limiting the commitment to what is "feasibly affordable."

The selection process is undermined if the package is, in fact, not affordable; however, defining what is affordable is constrained by the limited information on the costs of services. They also identify the main controversies in Uganda's experience, including (i) the role of the state and (ii) the scope for charging and/or exempting the poor. The second source of controversy is also related to some of the tensions between national and local guidelines for providing services.

The World Bank's (2001a) Ethiopia Public Expenditure Review (PER) finds that there are few cases, if any, where "a simple, direct and unambiguous connection" can be made between an intervention and a poverty outcome. It suggests that the problem be approached at three levels: (a) strengthening the availability and use of poverty information; (b) strengthening public expenditure management and the quality of information on public expenditure; and (c) making a more effective link between poverty information and expenditure management." (51)

The criteria for comparisons across sectors have a special emphasis on implementation constraints in the Zambia PER (World Bank 2001b). In particular, it recognizes that some social services may by design be intensive in skilled labor and require higher wages. Administrative constraints may also warrant alternative delivery techniques rather than "best practice." For example, where the implementation of a comprehensive primary health care program is difficult, dedicated immunization programs by visiting (i.e., non-permanent) staff may be more appropriate. 


\section{Appendix III. Tools and Techniques}

I. Reduced form regressions. These studies typically use single-country time-series data or cross-country time-series data to test the statistical relationship between the following: (1) components of public spending and economic growth (this is roughly equivalent to $Y(B, K, O))$; and (2) components of public spending and social indicators (this is roughly $B(Y, S, K, 0))$. The empirical evidence on the relative effectiveness of expenditure components has thus far been inconclusive. The robustness of the results is often sensitive to the empirical strategy employed and the countries and time period covered by the sample. The following gives a flavor of the techniques that have been used and their findings:

- Cross-country growth regressions. ${ }^{33}$ This typically uses panel data for a large cross-section of countries over time. A large empirical literature on economic growth has emerged since the early 1990s, due in part to developments in growth theory and the greater availability of cross-country macroeconomic data. Empirical studies of the link between expenditure policy and growth are reviewed in Baldacci, Clements, and Gupta (2003). Dollar and Kraay (2002) and Foster and Szekely (2001) (see Table 2) use aggregate cross-country data and cross-country micro data, respectively, to estimate the link between public spending and poverty. Both find a statistically significant effect of overall government consumption on poverty. Some studies use simple bivariate regressions using cross-country to examine the link between spending and poverty. ${ }^{34}$

- Time-series studies. Country studies using time-series data for fairly long time periods provide important evidence on the causal impact of intervention on economic growth. A recent study of the impact of education on growth in India over the 19661996 period, for example, suggests that it is primary education that ha a strong causal impact on growth, compared to other education levels (Self and Grabowski 2004). Researchers have also employed vector auto-regression (VAR) techniques to explore the time-series properties of public investment and growth, accounting for potential dynamic interrelationships without imposing a causal structure. A series of studies by Pereira $(2000,2001,2002)$ demonstrate the dynamic relationship between public investment in infrastructure and private output (private sector GDP, employment,

\footnotetext{
${ }^{33}$ Devarajan, Swaroop, and Zou (1995) using data on 29 countries over the 1970-1990 period suggest that public capital spending has a negative but insignificant effect on growth while current spending has a positive and significant impact on growth. They also find that transport and communication have a negative and significant impact on growth while health and education have a negative but insignificant impact on growth. In contrast, a study of 39 low-income countries over the 1990-2001 period finds that higher public expenditure on capital raises economic growth (Gupta, Clements, Baldacci, and Mulas-Granados 2003). A recent study finds that investment in education is the only expenditure outlay significantly associated with growth in a sample of 30 developing countries (Bose, Haque, and Osborn 2003).

${ }^{34}$ Mosley and Hudson (2001) estimate the correlation between expenditure components and poverty using cross-country data. Based on this exercise, they calculate a "pro-poor expenditure" (PPE) index or the ratio to GDP of spending components associated with poverty. In addition, results from recent cross-country regressions have been used to quantify the poverty elasticity of growth.
} 
and investment). A series of papers by Fan (see Table 2) use time-series data to estimate the relationship between public expenditure components in rural areas on both rural income growth and poverty reduction. The results suggest that there are large returns to agricultural research with respect to income growth and poverty reduction, though there are significant returns from other types of public spending as well. They examine spatial variations in income growth and poverty reduction and find that spending has the larger effects in poorer regions.

- Rates of return studies. Some studies use data drawn from household surveys to test the impact of education on individual earnings (rate of return to education) or aggregate data on public investment, output, and employment to estimate the returns to government investment. There is a large literature on rates of return to education investments (see for example Psacharopolous 1995), agricultural research (Roseboom 2002), infrastructure investments (Canning and Bennathan 2000), and in some cases, health investments (Schultz 1997 and 2002). However, the calculation of rates of return has typically been conducted to compare spending allocation within sectors. To the best of our knowledge, there has not been an attempt to compare these rates of return across sectors within a consistent empirical framework, due to the many technical difficulties inherent in such an exercise.

II. General equilibrium models. Computable General Equilibrium (CGE) models form a class of models where production activities, factors, and institutions and their links are fully specified. These require both national accounts and survey data. The data are compiled into a single information matrix (social accounting matrix (SAM)), where the links between activities, factors, and institutions are organized and calibrated using countryspecific parameters. Because they are technically demanding and data-intensive, they have been rarely used.

- Jung and Thorbecke (2003) apply and calibrate CGE models for Tanzania and Zambia. Their simulations suggest that a well-targeted education expenditure can be effective for growth and poverty alleviation. They also suggest that a sufficiently high level of physical investment is needed as well as an improved match between educational output and the structure of effective demand for labor.

- A dynamic CGE model of overlapping generations calibrated to Ghana suggests that reducing household costs of obtaining primary education has the largest short-run impact on growth and poverty reduction (Dabla-Norris and Matovu 2002).

The effects can be substantial even when higher education spending comes at the expense of infrastructure investment. Once universal basic education is achieved, however, tertiary education spending has the largest impact on growth.

III. Investment Appraisal. A large literature exists on techniques for evaluating the rate of return to specific investment projects (see Belli (1996) for a review of the literature). Are these useful from a poverty perspective? In assessing the role of project appraisal in World Bank lending, Devarajan, Squire, and Suthiwart-Narueput (1995) advocate a shift away from precise rates-of-return calculation to a broader appraisal of the rationale for public sector intervention; in particular, they suggest a careful assessment of counterfactual private sector supply response, the marginal costs of funds, and the fungibility of lending. 
Larsen and Rama (2003) present two practical ways of assessing the poverty impact of investment projects. The first, what they call "the project approach," calculates the ratio between the additional income generated by a project and its cost. Using this rate-of-return estimate, the nation-wide poverty-reducing effects of a project can be inferred, assuming the elasticity of poverty reduction to economic growth is known. The poverty impact is expressed as

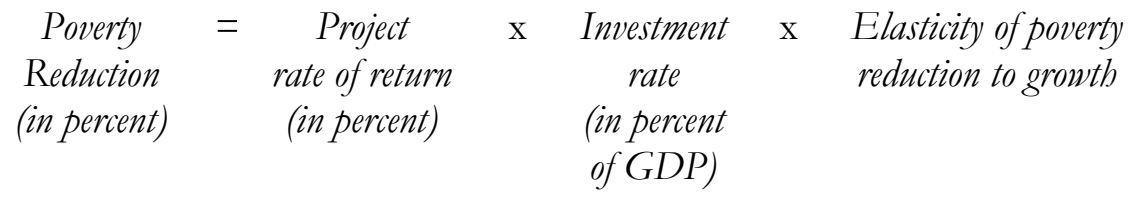

The second approach, what they call the "statistical approach," uses statistical information on the local poverty impact associated with local investment. The nation-wide poverty reduction impact is then expressed as

\begin{tabular}{|c|c|c|c|c|c|c|}
\hline $\begin{array}{l}\text { ty } \\
\text { ion } \\
\text { ent) }\end{array}$ & $=$ & $\begin{array}{c}\text { Statistical } \\
\text { impact } \\
\text { (local) }\end{array}$ & $\mathrm{x}$ & $\begin{array}{l}\text { Local poor } \\
\text { (in percent of } \\
\text { total poor) }\end{array}$ & $\mathrm{y}$ & $\begin{array}{c}\text { Investment rate } \\
\text { (in percent of } \\
G D P)\end{array}$ \\
\hline
\end{tabular}

Both approaches yield concrete estimates for the poverty reducing impact of investment projects, but they also suffer critical shortcomings. In particular, the project approach considers only direct effects of a project, ignoring indirect effects or externalities; the statistical approach considers only local effects ignoring effects transmitted to other communities or network effects. Notwithstanding these shortcomings, they provide useful benchmark figures for investment appraisal. For example, there are ongoing efforts to estimate the poverty impact of investment projects in Vietnam (Larsen and Rama 2003).

IV. Incidence analysis. Cross-country regressions and CGE models establish, in very broad terms, the links between expenditure components and poverty reduction. Another set of tools help clarify whether expenditure components indeed reach their intended final beneficiaries, whether these are individuals or local providers of services. These studies have been typically used to assess the efficiency and equity of the allocation of resources within sectors and, to a very limited extent, across sectors.

- Benefit incidence analysis. Benefit incidence analysis (BIA) use household survey data and information on public expenditure to assess the distribution of benefits among different groups, such as households at different income levels. BIA has been typically used to identify who benefits from public spending on education and health care (see Demery 2003, for a review of the literature). There are existing summary household survey data on access to water, sanitation, and other infrastructure by income quintiles (World Bank 2003a) that lend themselves to a benefit incidence analysis of infrastructure but studies of benefit incidence of expenditure items other than education and health care are rare. 
- Marginal incidence analysis. The usefulness of gauging the current average benefit incidence of public spending is generally acknowledged. However, there is some evidence that the marginal gains of the poor may be high, even for interventions that may not currently have a pro-poor average incidence (Lanjouw and Ravallion 1999). For example, tertiary education spending may not be pro-poor because it benefits mostly the top household quintiles but the marginal increase in tertiary education spending may primarily benefit the poorer quintiles. Ajwad and Wodon (2001) have recently used marginal incidence analysis to compare the impact of basic infrastructure

\section{Other quantitative tools.}

- Service delivery surveys. Some studies employ various quantitative techniques to assess the efficiency of service provision. For a number of reasons, some of them alluded to in the main text, information on the allocation of expenditures by sectors is a poor indicator of the quantity and quality of services actually provided in the frontlines. A number of empirical tools have been developed in recent years-including expenditure tracking surveys and quantitative service delivery surveys-designed to collect information at the service provider level and assess the quality and quantity of service provision. Dehn, Reinikka, and Svensson (2003) review the recent literature.

- Using household survey to derive allocation choices. Collier, Dercon, and Mackinnon (2002) illustrate a method for deriving a simple decision rule for allocating expenditures within the health sector. In particular, they present a model—within a framework that incorporates a utility function that depends on health status, a health production function, and a government budget constraint - that yields optimality conditions for allocating between recurrent (in this case, spending to improve quality) and capital spending (building more facilities). They use household survey data for Ethiopia to test their decision rule and find that it would be more efficient to allocate additional spending to improve the quality of health services rather than build more facilities. 